\title{
Selected Reference Books of 1978-79
}

\section{$\mathbf{T}$}

HIS ARTICLE continues the semiannual series originally edited by Constance $\mathrm{M}$. Winchell. Although it appears under a by-line, the list is a project of the Reference Department of the Columbia University Libraries, and notes are signed with the initials of the individual staff members. ${ }^{1}$

Since the purpose of the list is to present a selection of recent scholarly and general works of interest to reference workers in university libraries, it does not pretend to be either well balanced or comprehensive. A brief roundup of new editions of standard works, continuations, and supplements is presented at the end of the article. Code numbers (such as AE213, DB231) have been used to refer to titles in the Guide to Reference Books. ${ }^{2}$

\section{BIBLIOGRAPHY}

Tsien, Tsuen-hsuin. China: An Annotated Bibliography of Bibliographies. Boston, G. K. Hall, [1978]. 604p. \$45. LC 785541. ISBN 0-8161-8086-5.

Title also in Chinese.

Intended for both "specialists in Chinese studies and [for] students with a general interest" (Introd.), this comprehensive work on "all aspects of Chinese life and civilization" lists more than 2,500 bibliographies and bibliographical essays whether published separately, in periodicals and serials, or in monographs. Materials are chiefly in English, Chinese, and Japanese, with a small percentage in European languages. Emphasis is on recent (through 1977) and

1. Paul Cohen, Rita Keckeissen, Anita Lowry, Eileen Mcllvaine, Mary Ann Miller; Lehman Library: Laura Binkowski, Diane Goon.

2. Eugene P. Sheehy, Guide to Reference Books (9th ed.; Chicago: American Library Assn., 1976). comprehensive works, with some older materials included to illustrate development in certain subjects. Inclusion depends on "usefulness for information, study, or research" (Introd.), and selection varies "from one section to another, depending primarily upon the availability of sources." Where Western-language works were lacking or where supplementary information was needed, Chinese and Japanese works were listed.

Arrangement is in two parts of ten chapters each, with subdivisions (for language, subject, type of material) as appropriate. Part I, "General and Special Subjects," covers reference books, collective works, periodical lists and indexes, library catalogs, rare books, etc. Part II, "Subject Bibliographies," consists of chapters for classics and philosophy, religion, history, geography, social sciences, language, literature, art and archaeology, sciences, agriculture, and technology. Citations give full bibliographical information and a descriptive annotation; occasionally a critical comment is added. Chinese and Japanese titles appear in Oriental characters, romanization, and translation. The detailed table of contents, the list of Chinese and Japanese serials cited, and the author, title, and subject indexes, together with a lucid, succinct introduction, all serve to guide the reader and facilitate the search. - R.K.

\section{ARCHIVES}

Directory of Archives and Manuscript Repositories. Washington, National Archives and Records Service, 1978. 905p. \$25. LC 78-23870.

It has been four years since the National Historical Publications and Records Commission began work on the revision of Philip Hamer's Guide to Archives and Manuscripts 
(1961; Guide DB49). Questionnaires were sent to 3,200 archives and repositories throughout the country, and the data contained in the replies of the 2,700 respondents are presented here. Anxiously awaited (since Hamer's Guide is now almost twenty years old), the resulting work does not supersede its predecessor but does provide an updated companion.

A great deal of information is supplied in each entry. In addition to such useful information as hours of opening, terms of access, and holdings of repositories, there are descriptions of collections and bibliographical references. The latter include, not only citations to Hamer's Guide and the $\mathrm{Na}$ tional Union Catalog of Manuscript Collections, but also to library catalogs, brochures, checklists, bibliographies, and articles that describe various individual collections. Arrangement is geographical, and a long names/subject index-almost 125 pagesprovides an indispensable guide to the entries. Anyone looking for historical manuscripts should certainly begin the search with this directory.-P.C.

\section{BIOGRAPHY}

Biographical Dictionary of American Educators. Ed. by John F. 'Ohles. Westport, Conn., Greenwood Pr., 1978. $3 v$. (1,666p.) \$95. LC 77-84750. ISBN 0-8371-9893-3.

This dictionary offers 1,665 short biographies of American educators from the seventeenth to the twentieth centuries, the earliest representative being John Eliot, the famous missionary teacher. Over 400 contributors, most of them professors of education, participated in creating the work. The result is a handy, three-volume compilation, the chief virtue of which seems to be the convenience of having biographical data on so many educators in one place. As the bibliographical references at the end of each sketch readily indicate, most of those written about here are more fully-and in most cases, more satisfactorily-treated in other biographical dictionaries. However, this is not always the case: educators in certain special areas not generally included in the standard compilations are represented in this work. For example, here one finds biographical data on the leaders in industrial arts education, education of minorities, and textbook authors. The appendixes have useful geographical, chronological, and professional breakdowns, and the lengthy general index provides an additional guide to the entries. - P.C.

Biographical Dictionary of Japanese History. Seiichi Iwao, supervising ed., Burton Watson, trans. Tokyo, Kodansha International/USA Ltd., 1978. 655p. il. $\$ 39.50$. LC 76-9359. ISBN 0-87011-274-0.

The International Society for Educational Information has set itself the task of correcting errors of fact about Japan and Japanese culture found in foreign textbooks and reference works, and this dictionary is one of its efforts to prevent the continuing spread of misinformation. (Already published is the Biographical Dictionary of Japanese Literature [1976], and work has begun on a third volume concerned with notable figures in the fine arts.)

Happily, we are given much more than just the facts in this beautifully produced volume. Each short biography endeavors to convey the essence of the subject's character as well as the vital statistics and accomplishments. Thus through the lives of these carefully chosen "prime movers" and prominent citizens we are afforded an interesting view of Japan's political, social, religious, and scientific life from the age of myth and legend through the modern period.

Entries are arranged by period-“Ancient," "Medieval" (1185-1572), "Early modern" (1572-1868), and "Modern" (1868- ). The whole is indexed by name and subject. For the user's orientation in the social and political background of the biographies there are seventeen appendixes concerning such matters as family lineages, shogun lineages, Buddhist sects, bureaucracy and shogunate organizations, military actions, army and navy cliques, political parties, and cabinets. Finally, there is a bibliography offering from one to six references for each individual included in the dictionary.-M.A.M.

Lewytzkyj, Boris, and Stroynowski, Juliusz. Who's Who in the Socialist Countries. New York, K. G. Saur, 1978. 736p. \$99. LC 78-4068. ISBN 0-89664-011-6.

As the subtitle says, this is a "biographical 
encyclopedia of 10,000 leading personalities in 16 Communist countries." Although those sixteen countries are nowhere listed in the volume, they are: Albania, Bulgaria, Czechoslovakia, East Germany, Hungary, Poland, Romania, the Soviet Union, Yugoslavia, Cambodia, China, Korea, Laos, Mongolia, Vietnam, and Cuba. The Soviet Union and Eastern Europe receive very thorough coverage for all fields of endeavor, including politics, party activities, economics, the sciences and social sciences, the military, the arts, literature, history, philosophy, and religion. Cuba and the Asian countries, on the other hand, are represented primarily by government and party officials and diplomats. Although this work is meant to be a dictionary of basic biographical information on living persons, it also includes a number of important people who died during the past few years. For the most part, emigrés are excluded; dissidents and others in official disfavor who remain in Communist countries are included.

The compilers acknowledge the problems caused by the necessity of working from official sources (including newspapers), as well as the difficulties of reconciling conflicting accounts and of obtaining accurate, upto-date information. The amount of data provided varies from one entry to the next, but this is an extremely valuable source for information that is not available elsewhere in one place, and often not available elsewhere in English. $-A$. L.

\section{RELIGION}

Farmer, David Hugh. The Oxford Dictionary of Saints. Oxford, Clarendon Pr.; New York, Oxford Univ. Pr., [1978]. $£ 7.50 ; \$ 17.50$. LC 78-40445. ISBN 0-19869120-3.

Accounts of about a thousand saints of English origin, saints of foreign origin who died in England, and those who were known and venerated there make up this dictionary. All saints in the Book of Common Prayer, the Sarum rite, and the modern Roman calendar are included, as are representative saints of Ireland, Scotland, and Wales, and a few others important in the Christian church or in calendars other than the three mentioned. Byzantine saints are, in general, excluded.
The concise entries, none more than a page in length, give dates, alternate spellings of names, biographical information, history of a saint's cult in England, artistic associations (with reference to specific English works of art), and feast day. Bibliographies conclude the accounts, giving citations to official sources, the best hagiographical studies, and sometimes to popular works. There is a short appendix of entries for persons not formally canonized but for whom there is evidence of a popular cult in England at some period. An index of places in Great Britain and Ireland associated with particular saints will please readers interested in British local history and literature. The introduction is an interesting essay on English hagiography and the history of the cult of saints.-R.K.

Flake, Chad. A Mormon Bibliography, 1830-1930. Salt Lake City, Univ. of Utah Pr., 1978. 825p. \$75. LC 74-22639. ISBN 0-87480-016-1.

The tumultuous first century of Mormonism has produced a large and fascinating literature, the very richness of which has created a formidable task for its bibliographer. Chad Flake of Brigham Young University has spent many years preparing this bibliography and has compiled a work of more than 10,000 entries. Included are broadsides, pamphlets, books, and newspapers relating in some way to Mormonism. Some items have only a page or two on the subject, while others are wholly concerned with it; works of fiction are also included.

Items are arranged by main entry, and copies (and variant editions) have been located in some 200 libraries. Flake has also supplied historical and bibliographical notes for many of the entries. Collations are included, but unfortunately these are not given by signatures as one would expect in a work that is otherwise so thorough. Nevertheless, this is altogether a remarkable bibliography with attractive facsimile title pages at the beginning of each section.-P.C.

\section{LITERATURE}

Arbour, Roméo. L'Ère baroque en France; Répertoire chronologique des éditions de 
textes littéraires. Première partie, 1585 1615. Genève, Droz, 1977. 2v. (Histoire des idées et critique littéraire, V.165) F460.

Broadly interpreting the term "literary," the compiler of this bibliography has assembled references to more than 7,900 editions of literary texts published in France and French literary texts published abroad during the first half of the "baroque era." Scope extends to foreign-language works published in France as well as to French translations of foreign literary works. Within the yearby-year arrangement, listing is alphabetical by author or anonymous title, and there are indexes of names of persons, of editors, and of places of publication. Library locations (including many American institutions and European libraries outside France) are given whenever possible; source of the citation is provided when there is no known location. The completed work (the intention, presumably, is to extend coverage through 1640 at some future date) should prove useful to researchers in various areas of seventeenth-century studies, not to the specialist in French literature alone.-E.S.

Black American Writers: Bibliographical Essays. Ed. by M. Thomas Inge, Maurice Duke, and Jackson R. Bryer. New York, St. Martin's Pr., 1978. 2v. V.1, \$12.95; V.2, \$14.95. LC 77-85987. ISBN 0-31208260-6.

These two modest volumes succeed admirably in providing thorough, in-depth analyses of "the best biographical and critical writings" (Pref.) about twenty-four seminal black writers, not counting those represented in the section on "slave narratives." Volume 1 begins with three eighteenthcentury writers and includes the slave narratives, polemicists, early modern writers, the Harlem Renaissance, and Langston Hughes. Volume 2 is devoted to four major twentieth-century authors: Richard Wright, Ralph Ellison, James Baldwin, and Amiri Baraka (LeRoi Jones). The editors acknowledge that other important writers have come to prominence since the latter four, but they have imposed a chronological limit because of the perspective needed for this kind of work.

Each essay opens with discussion of the subject's bibliography, published editions, manuscripts, and letters. Writings about an author are grouped as biography (or autobiography) and as criticism (divided by genre). Focus is on the state of the art of the bibliography, biography, and criticism of the writers, e.g., the changing favor of Phillis Wheatley's work in the eyes of scholars; the difficulty of dating and locating the slave narratives; the elusiveness of Baraka's output published in obscure and unconventional sources. And each essay is generous with specific factual information. For any student or scholar interested in the black American writers here considered, these rigorously selective historical/critical essays are indispensable.-M.A.M.

\section{Libman, Valentina A. Amerikanskaia} literatura $v$ russkikh perevodakh $i$ kritike; bibtiografiia 1776-1975. Moskva, "Nauka," 1977. 451p. 2r., 94k.

Now updated and enlarged from its original form (1964) in the collection Problemy istorii literatury SShA of the Akademiia Nauk's Institut Mirovoi Literatury (a publication better known to American readers in the 1969 translated edition, Russian Studies of American Literature; see Guide BD273), this is a long bibliography of primary and secondary works reflecting the Russian interest in American literature over a long period of time.

In addition to the Russian translations of 230 American authors' works, there are included books, articles, reviews, and scholarly commentaries of research value by Russian, Soviet, and foreign authors of the nineteenth and twentieth centuries. The first section consists of two lists (each chronological by publication date): one on literary periods, the other on problems and themes in American literature. Then follows a short section on collections of American authors. The heart of the book is the third part, "Personalia," an alphabet of American authors, with the Russian translations of their works and Russian-language critiques. Not only full-length books, but short stories and poems appearing in Russian journals are cited. Full bibliographical information is given; there is a names/titles index. - R.K.

Marken, Jack W., comp. The American Indian: Language and Literature. Arlington Heights, Ill., AHM Publ. Corp., [1978]. 
205p. \$12.95; $\$ 8.95$ pa. LC 76-4624. ISBN 0-88295-569-1.

Marken has produced a typical bibliography in the Goldentree series: judiciously selected entries, balanced coverage of all aspects of the topic, yet not exhaustive despite the compiler's wish "to list all major and minor collections in an attempt to make this the best and most comprehensive bibliography available" (Pref.) of the literatures and languages of the Indians of North America (excluding Indians of Mexico and Central America and the Eskimo). Writings by American Indians are featured, although standard scholarly works are included as are secondary materials on non-Indian authors who wrote on the Indian (e.g., James Fenimore Cooper, Thomas Jefferson). Entries are presented geographically following the order in Murdock's Ethnographic Bibliography of North America (Guide CD28). with general sections of bibliographies, autobiographies, general literature, and general language. An asterisk beside an entry points up importance; a dagger indicates the availability of a paperback edition. The index is primarily by personal or tribal name, with some subject entries (which might profitably have been expanded to include jokes and riddles, songs, etc.).

There are a few omissions and mistakes that should be corrected for any future edition, and the compiler might consider the usefulness of some kind of chronological listing of literary works by American Indians. All in all, however, this is a useful bibliography for both the beginning student and the advanced researcher-easy to use, and with a wide range of sources cited. $-E . M$.

Ward, Philip. The Oxford Companion to Spanish Literature. Oxford, Clarendon Pr., 1978. 629p. \$27.50. LC 78-40098. ISBN 0-19-866114-2.

Students and librarians with little or no Spanish who needed a ready reference source for Spanish literature have long had to make do with the limited coverage of Newmark's Dictionary of Spanish Literature (Guide BD866) or glean what they could from the entries in the Diccionario de literatura española (Guide BD865). This new addition to the "Oxford companion" series, therefore, will be welcome as an English-language handbook covering a broad range of Spanish literary topics. Although more closely limited to authors and specific works than other "Oxford companions" (i.e., some literary terms are defined, but historical and political references are largely excluded), its geographic coverage is unusually wide: because "a great deal of literature in Spanish has been written beyond the geographical confines of Spain, ... . this necessitates the inclusion of entries on the more important authors and books" (Pref.) of the Central and South American countries (but not Brazil and Portugal). As might be expected, entries are accorded critics, historians, philosophers, etc., as well as the strictly creative writers. A particularly welcome feature is the inclusion of more bibliographic information than is generally found in the "Oxford companions."-E.S.

\section{Cinema}

Shale, Richard. Academy Awards. New York, F. Ungar, 1978. 615p. \$24.50. LC 78-4296. ISBN 0-8044-2819-0.

This is not just another coffee table book with many glossy photographs and few facts. Rather, it is a serious reference work providing a great deal of information on the Academy Awards from 1927/28 through 1977. Not merely the winners, but all the nominees in all categories are listed here, as well as the recipients of the special awards such as the scientific or technical awards, honorary awards, etc. In addition to the lists of nominees and winners (together with the citations for nomination) short historical notes trace the establishment, development, and other significant features for each award category; for example, the many changes in the awards for special effects are clearly explained. The work is in two main sections, a "Listing by Academy Award Categories" and a "Chronological Index of Academy Awards," so that full information can be found either by type of award or by year. (The chronological listing also gives the date that the nominations were announced, the date and location of the awards ceremony, and the MC for each year.)

The volume begins with a historical survey of the Academy of Motion Picture Arts and Sciences and the awards and ends with three useful appendixes ("Academy Founders," "Academy Presidents," and "Directors 
of Best Picture"), a selected, annotated bibliography, and an excellent index of names, titles, and subjects. Such thorough and accurate information on the first fifty years of "Oscar" should be welcome in many libraries.-A.L.

\section{FOLKLORE}

Szwed, John F., and Abrahams, Roger D. Afro-American Folk Culture: An Annotated Bibliography of Materials from North, Central and South America and the West.Indies. Philadelphia, Institute for the Study of Human Issues, [1978]. 2v. (American Folklore Society, Publs.: Bibliographical and Special Ser., V.3132) \$48. LC 77-16567. ISBN 0-91598080-0.

Contents: Part 1, North America; part 2, The West Indies, Central and South America.

The thesis around which this bibliography was assembled is that "Afro-American cultures exist, cultures which are neither entirely African nor Euro-American in origin, but which contain elements of both, plus the inevitable developments attendant upon enslavement, the plantation experience, $\mathrm{Na}$ tive American contact, poverty and racism, as well as the vigor and creativity of human beings."-Introd. In support thereof, the authors cite almost 7,000 published works on the values, symbols, language, and cultural expression of Afro-Americans, to be used with other bibliographies more concerned with the history, economics, and social organization of black people. Entries are grouped by linguistic or political division (e.g., English-speaking and French-speaking West Indies) and within each division, alphabetically by author. Most entries have very brief annotations unless the titles are self-explanatory.

The complete index appears in both volumes and consists of a general subject index and a locale index (excluding those areas listed in the tables of contents). The authors admit that indexing has not been easy because of the variance in detail of the annotations and the problem of generic classification of tales, songs, etc. As a result, the user will find detailed subject headings (e.g., "corn-shucking activities," with fourteen entries) and subject headings that are almost impossibly broad ("Africa: questions of antecedents and influences," covering almost two pages of entries). However, subject headings are subdivided by geographical division when appropriate, and numerous cross-references are provided.

Although the cutoff date (through 1973) is disappointingly early, academic libraries will find this a useful addition to reference collections in anthropology and black studies.-D.G.

\section{STATISTICS}

International Encyclopedia of Statistics. Ed. by William $\mathbf{H}$. Kruskal and Judith $\mathbf{M}$. Tanur. New York, Free Pr., 1978. 2v. $(1,350$ p.) \$100. LC 78-17324. ISBN 0-02917960-2.

For this compilation the editors have used as a basis all the articles relating to statistics from the International Encyclopedia of the Social Sciences (Guide CA44) and have added some twenty-two new articles dealing with statistics in the broadest sense. Thus besides articles bearing directly on statistics, such as "Errors," "Life Tables," etc., there are biographies of "statisticians and others important in the development of statistics" and "a considerable number of articles about fields in which statistical methods are significantly applied, for example, epidemiology, public policy . .."-Introd.

In order to update the articles from the parent work, each original author was given the option of rewriting his or her article, amending it, or adding a postscript; each author was requested to update the bibliography. Only a few of the articles are exactly as they appeared in the 1968 work. Bibliographies have been updated to about $1973 / 74$ and are designed to "contain explicit suggestions for further reading, sources for further bibliography, sources for historical and current data, and the titles of journals concerned more or less exclusively with the topic of the article." References in the bibliographies to articles in the IESS seem an unnecessary addition.

The articles and postscripts are wellwritten, beginning with a general, nontechnical summary and proceeding to a thorough discussion of the topic. Indexing is very detailed, and scholars names cited in the text are included. This is a carefully 
edited compendium, useful to the student or researcher at any level.-E.M.

\section{POLITICAL SCIENCE}

Encyclopedia of American Foreign Policy: Studies of the Principal Movements and Ideas. Ed. by Alexander DeConde. New York, Scribner, 1978. 3v. (1,201p.) \$99. LC 78-5453. ISBN 0-6841-5503-6.

This three-volume collection of essays, written and signed by scholars in the field, is organized alphabetically by topics ranging from "Alliances, Coalitions and Ententes" to "Unconditional Surrender." Enlightening and highly readable, the articles focus on a conceptual analysis of major themes, theories, doctrines, and distinctive policies in the history of American foreign relations, tracing ideas with consistency and continuity. Specific events are mentioned only when they relate to the broader discussion. Coverage is selective, but at times, very imaginative-for example, the articles on "Ethnicity and Foreign Policy," "Missionary Diplomacy," and "Protection of American Citizens Abroad." Each essay concludes with a short bibliography and a list of cross-references to related articles; there is a detailed index.

An added feature is a biographical section of over 500 entries on prominent persons in the history of American foreign policy: presidents, diplomats, politicians, journalists, and other public figures. One must virtually stumble upon this section since it is not mentioned in the table of contents or the preface, and the entries are not keyed into the index. Although this factual information is useful, its inclusion appears to be a last minute padding by the publisher in order to stretch the work to three volumes. Librarians and readers alike would have been just as pleased with a solid two-volume collection of valuable essays and a less expensive price tag. - L.B.

\section{HISTORY \& AREA STUDIES}

Herwijnen, G. van. Bibliografie van de stedengeschiedenis van Nederland. Leiden, Brill, 1978. 355p. fl.80. ISBN 90-04-05700-5.

At head of title: Acta collegii historiae urbanae societatis historicorum internationalis.
This is the latest addition to the series of bibliographies sponsored by the International Commission for the History of Towns. The 3,331 items relating to urban history in the Netherlands include books, periodical articles, and academic dissertations. Basic arrangement is by province, subdivided by specific city or town; thereunder, items appear in a topical arrangement according to a scheme outlined in the prefatory pages. There are indexes of place-names and of authors. - E.S.

Horak, Stephan M. Russia, the USSR, and Eastern Europe: A Bibliographic Guide to English Language Publications, 19641974. Ed. by Rosemary Neiswender. Littleton, Colo., Libraries Unlimited, 1978. 488p. \$25. LC 77-20696. ISBN 0-87287178-9.

Students, researchers and librarians, to whom this volume is addressed, will welcome it as a ten-year extension of Paul Horecky's basic bibliographies, Russia and the Soviet Union (Guide DC361), East Central Europe (Guide DC17), and Southeastern Europe (Guide DC18). Although originally undertaken as a revision of the compiler's Junior Slavica (Guide DC359), it serves effectively as a selective updating of the Horecky titles, listing about 1,600 English-language monographic works in the social sciences and humanities for almost all the subject areas of those volumes. There are three main divisions: (1) general works on the USSR, Eastern Europe, and Communism; (2) more specific topics concerning Russia to 1917, the Soviet Union, the nonRussian Soviet republics, and Jews in the USSR; (3) Eastern Europe. Each section is appropriately subdivided by topic o country. Although non-Slavic Eastern Europe (East Germany, Hungary, Romania, and Albania) is included "for geographic and political reasons" (Introd.), Greece, which had a chapter in Southeastern Europe, is excluded, as is the historical Byzantine Empire. Parts 1 and 2 constitute about threequarters of the list, with more than 1,200 entries. Each entry gives full bibliographic information and carries a descriptive and critical annotation excerpted from a signed book review in a leading Slavic studies journal. There is an author/title index and one of subjects. - R.K. 
Witherell, Julian W. The United States and Africa: Guide to U.S. Official Documents and Government-Sponsored Publications on Africa, 1785-1975. Washington, Library of Congress, 1978. 949p. $\$ 14.75$. LC 78-1051. ISBN 0-8444-0261-3.

Witherell has here compiled a bibliography of selected publications issued by or for the United States government relating to any part of Africa (with the exception of Egypt), including the islands of the southeast Atlantic and western Indian Ocean. The first four sections-covering 1785-1819, 1820-1862, 1863-1920, 1921-1951-are "limited primarily to congressional and presidential documents, commercial reports, diplomatic treaties" (Pref.) and are subdivided geographically. A few National Archives microfilms are included for the first period.

The final section, 1952-1975, adds to the listing of the above types of government publications "translations issued by Joint Publications Research Service and printed and mimeographed studies concerning American assistance programs prepared by or for federal government agencies" (so long as they are unclassified). This part, comprising about 80 percent of the entries, is also arranged geographically and further subdivided by broad topic. Library of Congress call numbers are given for most entries; for those not available at LC, location symbols for other libraries are given. Indexing is by topic, main entry, and issuing body. $-E . M$.

\section{Historical AtLases}

A Historical Atlas of South Asia. Ed. by Joseph E. Schwartzberg. Chicago, Univ. of Chicago Pr., 1978. 352p. 41cm. il., maps. (Assn. for Asian Studies. Reference Ser., no.2) $\$ 150$. LC $77-81713$. ISBN 0-226-74221-0.

Many years in planning and preparation, this atlas is indeed an impressive publication. It "seeks to provide a comprehensive cartographic record of the history of South Asia from the Old Stone Age to the present day" (Introd.), with history taken to mean "not merely the recounting, analysis, and interpretation of political events, but also the consideration of cultural, social, demographic, and economic developments."

The 149 pages of maps and plates are presented in fourteen principal sections, and the explanatory text that follows is similarly arranged. Section I is designated as "the physical stage," section II as "prehistory." Sections III-IX deal with significant historical periods, the emphasis in these sections being on political history, but with some attention to social and cultural processes. Sections X-XI are concerned with social, cultural, economic, and demographic evolution; section XII is devoted to the rural and urban settlement pattern of India; section XIII is intended as an aid to detailed regional study; and the final section offers a "geopolitical analysis." Maps (nearly all in color) are mainly at the scale of $1: 12,700,000$; and two overlay maps, one indicating physiography, the other administrative divisions as of 1975 , are found in the pocket at back (along with three folded chronological charts).

A general bibliography is provided at the end of the introduction to each section of text, with references to sources and specialized bibliography following individual subsections. The main bibliography (p.267304 ), a classified listing of some 4,000 items, is in itself a substantial reference source. The detailed index lists not only regions, places, movements, and other mappable features shown in the atlas but includes names of persons mentioned in the text and the major subject headings. $-E . S$.

The Times Atlas of World History. Ed. by Geoffrey Barraclough. Maplewood, N.J.: Hammond, [1978]. 360p. $37 \mathrm{~cm}$. \$50. LC 78-5403. ISBN 0-8437-1125-6.

Departing from the more usual approach in the presentation of history through maps, Barraclough and his contributors have shifted from a political and Europe-centered view to an emphasis on change, on economic and social history, and on international movements, thus presenting "a view of world history appropriate to the age in which we live."-Introd. Each map is original and is accompanied by commentary, densely packed with data, written by a specialist. Although the maps are informative, handsome, and generally clear, two reservations may be noted. In a few maps the variations in color are not distinct enough, e.g., the yellows on the map on p.72-73, or the browns on p.99. The other reservation 
concerns the absence of reference to scale; lines indicating latitude and longitude appear on some maps, but a note on conversion of latitude/longitude to miles or kilometers would have been useful.

Maps and commentary cover every period from "Hunters and Gatherers" to "The Eurasian World in 814" to "The World in 1975: Rich Nations and Poor Nations." There is a world chronology that lists major events in regional columns, with a separate column for cultural events (including developments in science and technology). A glossary of names "of individuals, peoples, events, treaties, etc., which .... received only brief mention on the maps and accompanying texts" is separate from the index of geographical names.

The volume seems well made, lies flat when opened, and should not need rebinding soon-which is fortunate, since there are many double-page maps with little or no inner margin. - E.M.

\section{NEW EdITIONS, SUPPLEMENTS, ETC.}

Described as the "third and last" supplement to the British Museum's General Catalogue of Printed Books (Guide AA100), the Five-Year Supplement, 1971-1975 (London, publ. for the British Library by British Museum Publs. Ltd., 1978- . To be in 13v.) will include nearly 600,000 entries (about 400,000 main entries plus added entries and references) for works cataloged 1971-75. Later information about the library's holdings is to be made available through the "products and services" derived from the British Library data base of machine-readable records. Changes in cataloging procedures (designed to bring entries nearer to conformity with AngloAmerican cataloging rules) were gradually introduced during the period of coverage and are reflected in the Supplementparticularly in regard to entries for serials and anonymous books. Thus some serials are entered by title, while others are grouped under the heading "Periodical Publications" according to the older practice. Reduction in the size of entries and use of a three-column page has resulted in a smaller number of volumes and a lower cost for the set, but the text is legible and the pages attractive despite the small print.
The publication gap in the Bibliothèque Nationale's Catalogue général ... (Guide AA105) has been closed with the appearance of V.214 (Paris, Imprimerie Nationale, 1978. $2 \mathrm{v}$.), which is devoted to Voltaire. In order to provide a useful and up-to-date bibliography of Voltaire's writings, a departure was made from the established rules for the Catalogue: rather than the 1959 cutoff date observed since V.189, some editions of his works published up to 1978 have been included. Moreover, 239 pages of indexes (of titles, of incipits of works in verse, of translations and adaptations, of pseudonyms, of names cited, of illustrators, etc.) precede the 1,824 columns of catalog entries in this impressive compilation.

Some 69,650 titles published throughout the world through 1974 are listed in the third edition of Eleanora A. Baer's Titles in Series (Metuchen, N.J., Scarecrow Pr., 1978. 4v. \$95). In addition to all works included in earlier editions (Guide AA90) and titles in newly published series, some older series have been added for the first time.

The second edition of Books in Series in the United States (New York, Bowker, 1979. 3,273 p. \$62.50) "provides access to some 113,154 titles issued by some 1,270 publishers and distributors in some 10,837 series."-Pref. It cumulates the information from the first edition (1977) and its 1978 supplement, together with additional entries providing both current and retrospective coverage (i.e., date of publication is no longer a criterion for inclusion); future editions will close gaps in retrospective listings and also add data for new and ongoing series.

Anne Lyon Haight's Banned Books, 387 B.C. to 1978 A.D. has appeared in a fourth edition updated and enlarged by Chandler B. Grannis (New York, Bowker, 1978. 196p. $\$ 13.95)$. Besides the addition of about sixty items, there is a new introductory essay, "Censorship in America: The Legal Picture," by Charles Rembar.

About 6,500 periodicals are annotated and evaluated in the third edition of Magazines for Libraries by William A. Katz and Berry G. Richards (New York, Bowker, 1978. 937p. \$37.50). As in earlier editions, "titles have been selected to include (1) some general, nonspecialist periodicals of interest to the layperson; (2) the main English-language 
research journals sponsored by distinguished societies in the United States, Canada, and Great Britain; and (3) some high-quality commercial publications commonly found in academic/special libraries."-Pref. About 95 percent of the annotations from previous editions (see Guide AA419a) were edited and revised for this edition.

Numerous revisions and changes, as well as general updating, characterize the second edition of Joe Morehead's Introduction to United States Public Documents (Littleton, Colo., Libraries Unlimited, 1978. 377p. $\$ 17.50)$. One significant change is that "chapters on the publications of the several departments, agencies, and independent establishments now emphasize categories of materials rather than a lengthy recital of individual titles and series" (Pref.) as in the 1975 edition.

Walter L. Newsome's New Guide to Popular Government Publications for $\mathrm{Li}$ braries and Home Reference (Littleton, Colo., Libraries Unlimited, 1978. 370p. $\$ 18.50)$ is a revised and updated edition of Linda C. Pohle's Guide to Popular Government Publications (1972; Guide AG12). Arrangement remains basically the same, but annotations have been rewritten. "Currency or long-term popular interest has been the primary selection criterion for the approximately 2,500 titles in this edition."-Introd.

Information on approximately 39,000 currently active scholars in the humanities (4,700 appearing for the first time) is provided in the seventh edition of the Directory of American Scholars (New York, Bowker, 1978. 4v. \$165). Division into volumes is the same as for the previous edition (1974); there is a geographic index in each of the four volumes, and a combined index of scholars in volume 4.

The promised supplement to the Dictionary of Scientific Biography has been published as V.15 of the set (see Guide EA225). Approximately two-thirds of this new volume (N.Y., Scribner, 1978. 818p.) is an alphabetical arrangement of biographical sketches of persons from all periods (references to many of these articles having appeared in the main sequence of volumes); the balance of the work comprises a series of topical essays on aspects of the history of science in India, Mesopotamia, ancient Egypt, and Japan, plus an essay on "Maya Numeration, Computation, and Calendrical Astronomy." An index to the full set has yet to appear.

The Eighteenth Century: A Current Bibliography has begun a new series (Philadelphia, American Society for EighteenthCentury Studies, 1978- . n.s.V.1-

$\$ 25)$ and is no longer issued as part of Philological Quarterly (see Guide BD16). The first volume covers. publications of 1975 and continues the broadened coverage instituted when the annual bibliography "English Literature 1660-1800" (Guide BD396) adopted the new title in 1971. The bibliography covering 1973 (published 1974) was the last to appear in $P$.Q.

French 17 (Fort Collins, Colo., Colorado State Univ., 1978- . no.26- \$2.25 pa.) represents a change of title for the $B i b$ liography of French Seventeenth Century Studies (Guide BD730). Published for the Seventeenth Century French Division of the Modern Language Association of America, the new series continues the coverage of the earlier annual and assumes its numbering.

Esther Spring Arata's More Black American Playwrights (Metuchen, N.J., Scarecrow Pr., 1978. 321p. \$13.50) forms a supplement to her Black American Playwrights. "Approximately 490 playwrights appear in this bibliography, of which 190 appeared in the 1976 edition."-Pref.

Although it bears a different title, Safire's Political Dictionary by William Safire (New York, Random House, 1978. 845p. \$15.95) is presented as the "third edition" of The New Language of Politics (Guide CJ49), considerably enlarged and updated.

The fifth and final volume of Sources in British Political History, 1900-1951, compiled by Chris Cook and Jeffrey Weeks, is entitled "A Guide to the Private Papers of Selected Writers, Intellectuals, and Publicists" (London, Macmillan, 1978. 221p. $£ 20$ ). It lists, locates, and briefly describes an interesting array of relevant collections in numerous United States repositories as well as those in Great Britain and other Commonwealth nations. - E.S. 


\section{we've put together a new international directory...}

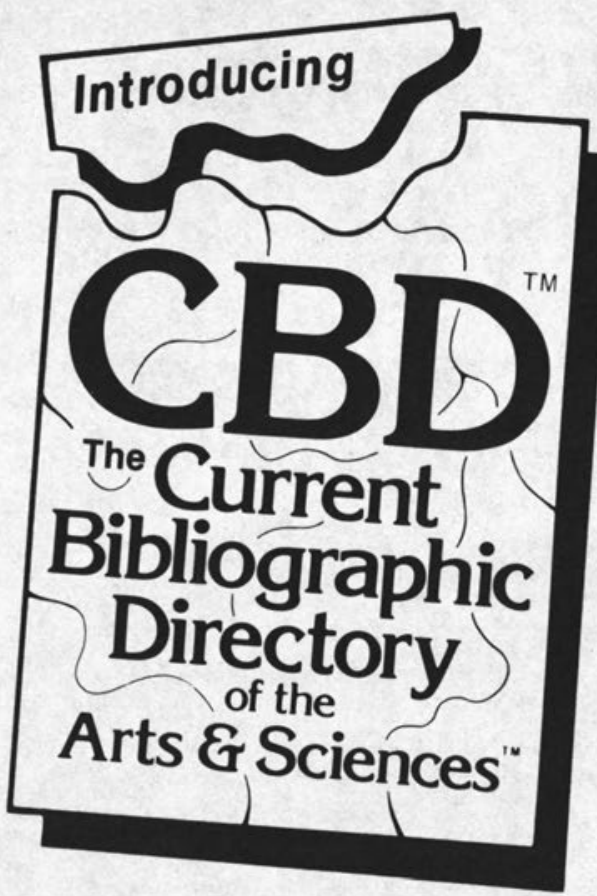

What does CBD cover?

CBD includes authors from over 6,200 worldwide journals and 1,400 books and contains...

- the names and addresses of over 365,000 authors publishing annually in the sciences, social sciences, arts and humanities

- abbreviated citations for each author's publications for the year covered

- three separate sections for easily identifying authors and institutions - the Geographic Section, Organization Section and the Author Section What will CBD do for me?

$C B D$ is an excellent tool for locating authors' addresses for reprint requests ... verifying publications quickly and easily. . verifying spelling of an author's name, or determining the names of authors associated with a particular organization. . .quickly differentiating between authors with similar names. . determining what organizations are located in an area and who in those organizations you might want to contact. . evaluating the output of a region or community, or of a specific organization.

But let our FREE brochure introduce you to CBD. It will show you sample entries and suggestions on how to use this unique publication. To receive your copy, just complete the coupon and mail it to ISI .

\section{name and address list.}

$\square$ Please send me more information about your new international directory - the CURRENT BIBLIOGRAPHIC DIRECTORY of the ARTS \& SCIENCES. ${ }^{\text {TM }}$

Name Title

Organization Dept.

Address

City State/Province ZIP 


\title{
"Wesp speak yourlanguage...
and theirs too."
}

Consolidate Your British and European Journals with Blackwell's and.....

\author{
Make use of the REAL experts \\ - Speed of Information \\ - Locality \\ - European Language Skills
}

Plus all the advantages of a tried and tested computer system

- Automatic Renewal

- Customized Periodicals Information Bulletin

- Personal Contactin Oxford

- Local Representation in USA

- Close Agency/Publisher Relationship

- Machine Readable Invoices

- Back Issue and Microform Services
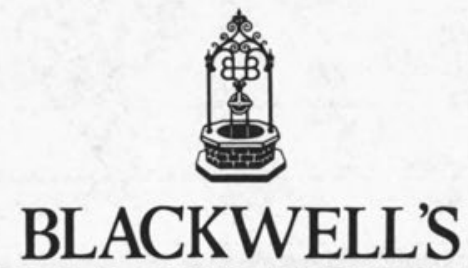

PO.BOX 40 OXFORD ENGLAND OXI 2EU 